\title{
The PalaeoAffad Project and the Prehistory of the Middle Nile
}

\author{
Marta Osypińskaa ${ }^{a}$ Piotr Osypiński ${ }^{b}$, Marek Chłodnicki ${ }^{c}$, \\ Michał Kuc $^{d}$, Paweł Wiktorowicz ${ }^{e}$ and Robert Ryndziewicz $f$
}

\begin{abstract}
Current work on the PalaeoAffad Project allows us to contribute greatly to the legacy of prehistoric research in the Middle Nile Valley. This paper presents the state of research on Late Pleistocene settlement on both banks of the river. Based on absolute dates obtained in the Affad Basin (since MIS5 up to the 5 th millennium BP), the prehistory of the area has become an important reference point for general NE-African studies. We were able to investigate most of the Palaeolithic sites there before the landscape was totally changed by the industrial farms in areas that had been inaccessible for traditional agriculture up to now.
\end{abstract}

KEY-WORDS: Archaeological heritage, Prehistory, Southern Dongola Reach, Sudan

\section{INTRODUCTION}

In taking his first steps in Africa, the Polish archaeologist Michał Kobusiewicz participated in the Combined Prehistoric Expedition (CPE) research project near Debba. At the end of the I960s, the area was poorly urbanized, and archaeological research was not yet facing the threat of site annihilation. Nevertheless, this expedition, led by Anthony Marks, never returned to the Southern Dongola Reach. The involvement

a Institute of Archaeology and Ethnology, Polish Academy of Sciences, Rubież Street 46, 6I-6I2 Poznan, Poland; e-mail: archeozoo@o2.pl; ORCID: 0000-0003-4603-9245

$b$ Institute of Archaeology and Ethnology, Polish Academy of Sciences; Rubież Street 46, 6I-6I2 Poznan, Poland; e-mail: piotr.osypinski@gmail.com; ORCID: 0000-0001-7843-224X

c Archaeological Museum in Poznan; Wodna Street 27, 6I-78I Poznan, Poland. e-mail: mchlod@man. poznan.pl; ORCID: 0000-0002-1728-464X

d Independent Researcher, Wroclaw; e-mail: kucmicha@gmail.com; ORCID: 0000-0003-4828-3778

$e$ Institute of Archaeology and Ethnology, Polish Academy of Sciences; Rubież Street 46, 6I-6I2 Poznan, Poland; e-mail: wiktorowicz@iaepan.poznan.pl; ORCID: 0000-0002-3897-0948

$f$ Institute of Archaeology and Ethnology, Polish Academy of Sciences; Al. Solidarności Io5, oO-I40 Warsaw, Poland; e-mail: robert.ryndziewicz@gmail.com; ORCID: 0000-0002-8443-8362 


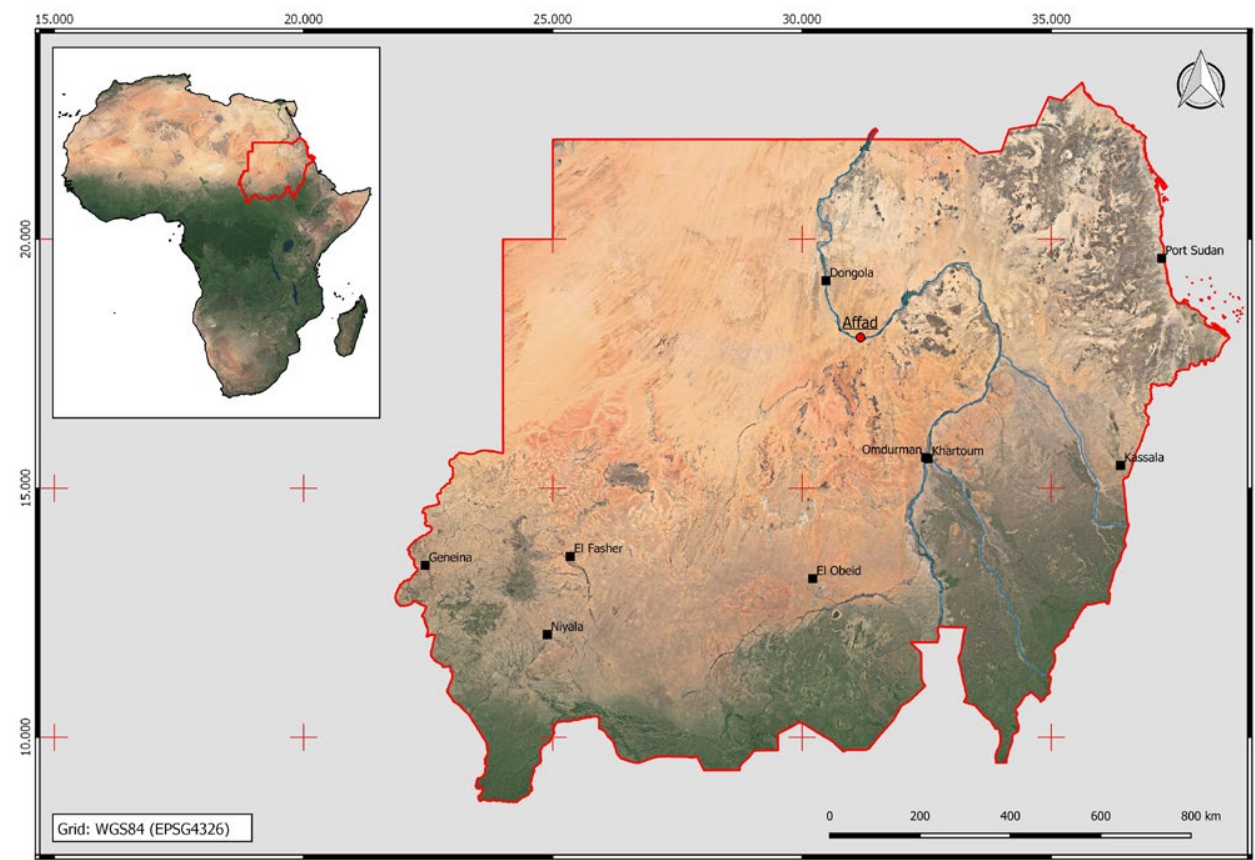

Fig. I. Location of the Affad Basin (Southern Dongola Reach). Satellite image: ESRI. Computer graphics: P. Wiktorowicz.

of Professor Kobusiewicz, however, was not forgotten and in the mid-I99os he was invited once again to participate in a Nubian Stone Age research project, this time by the Royal Ontario Museum which conducted a survey on the right bank of the Nile. The prehistoric sites discovered at that time attracted the attention of the project leader, Krzysztof Grzymski, who decided to entrust them to experienced prehistorians from Poznan. According to the account of the professor himself, Jebel Kobkabba - the name of a small rocky hill where the research trench was set up - commemorated the names of Kobusiewicz and Kabaciński.

Until 1997, no comprehensive research had been conducted on the Stone Age in this part of the Nile Valley (Fig. I). Only one other project, directed by Bogdan Zurawski, marked the beginning of a wide-range, multi-aspect survey of prehistoric settlement remnants on the right bank of the Nile from Old Dongola, to the suburbs of ancient Napata. At that time, 300 locations of Stone Age chronology were recorded in a zone several hundred metres wide in what was then a belt touching the crops and settlement. At that time, Sudan did not differ significantly from what Prof. Kobusiewicz had known from his CPE research. As it seems now, these were to be the last 


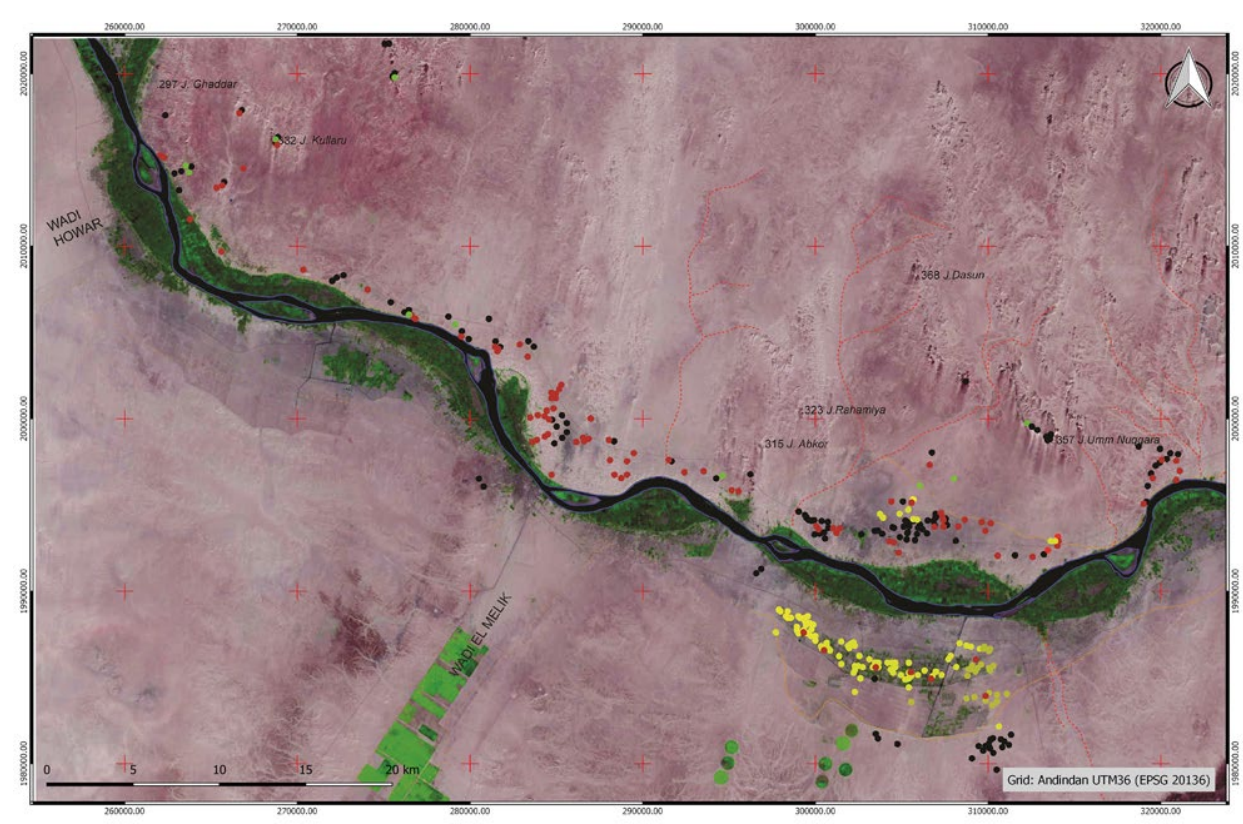

Fig. 2. Location of prehistoric sites in Southern Dongola Reach (all projects described in this text). The background - satellite image (Landsat 7) and modern range of agricultural crops.

Chronology of prehistoric sites: green - ESA; black - MSA; red - early Holocene (Mesolithic / Early Neolithic); yellow - middle Holocene (Middle Neolithic).

Computer graphics: P. Wiktorowicz and P. Osypiński.

years of such conditions in the middle part of the Nile Valley, namely with electricity provided solely from generators, a sparse telecommunications network and a lack of paved roads and bridges. It was also the most urgent time to record the landscape of the past cultures of this area. Indeed, within just two decades, most archaeological sites discovered by Southern Dongola Reach Survey (SDRS) have ceased to exist.

This essay presents the current state of knowledge about the settlement at Southern Dongola Reach during the Stone Age (Table I) contributed by the PalaeoAffad Project. ${ }^{1}$ Exploration of both banks of the Nile was presented in geographical and historical order addressing the advances in prehistoric archaeology of Africa in general. The example of the Affad Basin micro-region, shows also the scale of irreparable damage to the preserved cultural heritage that has occurred in this region over the last two decades (Fig. 2).

1 Project financed by a research grant of the National Science Centre, Poland: UMO-2015/18/E/HS3/00416. 
Table I. Summary of the Southern Dongola Reach prehistory. The secondary context of the artefats occurence marked in italics. Chronological estimations based on new dates from the PalaeoAffad Project to be published soon with extensive comments of specialists in the luminescence and electro-spin resonance dating. MIS - Marine Isotope Stage.

\begin{tabular}{|c|c|c|c|c|c|c|c|}
\hline MULTAGA & CPE & $\begin{array}{l}\text { LEFT } \\
\text { BANK }\end{array}$ & $\begin{array}{c}\text { time flow } \\
\text { (ka) }\end{array}$ & $\begin{array}{l}\text { RIGHT } \\
\text { BANK }\end{array}$ & $\begin{array}{c}\text { SDRS - } \\
\text { MTC I } \\
\text { (Mode 2) }\end{array}$ & $\begin{array}{c}\text { SDRS - } \\
\text { MTC II } \\
\text { (Mode 3) }\end{array}$ & $\begin{array}{l}\text { SDRS - } \\
\text { MTC IV } \\
\text { (Mode 5) }\end{array}$ \\
\hline & & & & inselbergs & 9 loci & & \\
\hline & sec. 3 loci & & pre-MIS5 & $\begin{array}{c}\text { eroded } \\
\text { palaeosoil }\end{array}$ & $\begin{array}{l}\text { Afd } 115, \\
\text { Afd } 118\end{array}$ & & \\
\hline
\end{tabular}

\begin{tabular}{|c|c|c|c|c|c|}
\hline \multicolumn{6}{|c|}{ MIS5 since $130 \mathrm{ka}$} \\
\hline & sec. 4 loci & & & inselbergs & $\begin{array}{l}\text { J. Kobakabba } \\
+c .30 \text { loci }\end{array}$ \\
\hline $\begin{array}{l}93 \text { (L.3), } 97 \text { (L.3), } \\
\text { 106, } 108- \\
\text { Nubian Complex }\end{array}$ & $\begin{array}{c}\mathrm{N} 2- \\
\text { Sangoa/ } \\
\text { Lupemban }\end{array}$ & $\begin{array}{l}\text { reddish-brown } \\
\text { silt with } \\
\text { concretions }\end{array}$ & $\begin{array}{r}134 \pm 13 \\
92.1 \pm 7.9 \\
76.5 \pm 7.0\end{array}$ & reddish sand & \\
\hline
\end{tabular}

MIS4 since $74 \mathrm{ka}$

\begin{tabular}{|c|c|c|c|c|c|}
\hline $\begin{array}{l}\text { sec. } 93 \text { (L.2), } \\
97 \text { (L.2) - } \\
\text { Nubian Complex } \\
+ \text { tanged tools }\end{array}$ & $\begin{array}{l}\text { N6- } \\
\text { "Khormusan-like" }\end{array}$ & $\begin{array}{l}\text { erosion - } \\
\text { gravels, sands }\end{array}$ & $\begin{array}{c}>40 \\
51.5 \pm 4.8 \\
25.3 \pm 2.1\end{array}$ & gravel sheet & $\begin{array}{c}\text { sec. Afd121, } \\
\text { Afd119, } \\
\text { Afd108 }\end{array}$ \\
\hline
\end{tabular}

tanged tools

MIS3 since $60 \mathrm{ka}$

\begin{tabular}{l|ll}
$60.1 \pm 8.7$ & clay, silts & \\
$57.8 \pm 9.6$ & & \\
$56.8 \pm 4.8$ & sand, silts & Afd23, Afd111 \\
$46.0 \pm 4.8$ & & Afd131, Afd24 \\
& & Afd124, Afd134 \\
$42.5 \pm 6.3$ & silt & second. $>100$ loci
\end{tabular}

MIS2 since $24 \mathrm{ka}$

\begin{tabular}{|c|c|c|c|c|c|}
\hline \multirow{3}{*}{$\begin{array}{l}\text { MTG3 } \\
+6 \text { loci }\end{array}$} & & $\begin{array}{c}\text { Girra } \\
\text { formation, }\end{array}$ & $8.8-8.5$ & $\begin{array}{c}\text { eroded } \\
\text { palaeosoil }\end{array}$ & $\begin{array}{l}\text { Afd128, } \\
\text { Afd121 }\end{array}$ \\
\hline & Karmakol - 7 loci & $\begin{array}{c}\text { eroded } \\
\text { palaeosoil }\end{array}$ & $8.4-8.2$ & $\begin{array}{c}\text { eroded } \\
\text { palaeosoil }\end{array}$ & $\begin{array}{c}\text { Afd125 } \\
+>100 \text { loci }\end{array}$ \\
\hline & Tergis - 8 loci & & & & \\
\hline \multirow{4}{*}{65 loci } & \multirow{3}{*}{ Karat - 19 loci } & \multirow{3}{*}{$\begin{array}{l}\text { eroded } \\
\text { palaeosoil }\end{array}$} & $7.0-6.8$ & $\begin{array}{l}\text { eroded } \\
\text { paleosoil }\end{array}$ & Afd119 \\
\hline & & & $6.5-6.2$ & $\begin{array}{c}\text { eroded } \\
\text { palaeosoil }\end{array}$ & $>10$ loci \\
\hline & & & $6.2-5.9$ & $\begin{array}{c}\text { eroded } \\
\text { palaeosoil }\end{array}$ & Afd130 \\
\hline & loci & & & & \\
\hline
\end{tabular}

\section{MIS1 since 11 ka}




\section{STONE AGE SITES ON THE LEFT BANK OF THE NILE}

\section{The Stone Age as revealed by the Combined Prehistoric Expedition}

The area between Debba and Korti was chosen in 1966 by researchers from the Southern Methodist University (Marks et al., 1968; de Heinzelin 1968) as suitable for obtaining material referring to finds from Lower Nubia (Wendorf 1968) and expanding our knowledge of the prehistory of sub-Saharan Africa. This area was located far to the south of Batn el-Hajar, a cataract (II) recognized as an eternal border area of cultural zones along the river. It also embraced the mouth of a large ephemeral river channel, Wadi el-Melik, crossing the southern areas up to Kordofan. Geological units (formations) of two stages of river sedimentation revealed the presence of Stone Age settlement remains. Most of the "early-ceramic" sites were recorded on the surface of the Girra alluvial formation terraces, divided into named groups: Early Khartoum Related (Karmakol, according to Hays I97ıa), Tergis, Karat and El-Melik (following their chronological position: Hays 197Ib; Marks and Ferring 1971; Shiner 197I). In turn, the Goshabi formation had a three-part structure in a normal stratigraphic succession. The base of the formation was made of calcacerous silts, with fluvial sands being deposited above them, while the top was made of gravels. Collections of lithics were recorded in situ within the sands, and on the surface of the silt layers. Three assemblages of Palaeolithic artefacts originated from the Goshabi formation: N2 (identified by the presence of bifacial forms as the Sangoa/Lupemban industry), the relatively younger N6 (without bifacial forms - identified as Khormusan-related industry) and the least characteristic and one derived from a secondary context, namely N91.

The next research on the late Pleistocene and Holocene geological development of the Nile valley produced new interpretations of finds from the vicinity of Debba. Fred Wendorf and Romuald Schild (Wendorf and Schild 1992: 45) believed that the Goshabi formation sediments corresponded to late-Middle Palaeolithic valley alluviation and should be dated slightly later than 70 ka (kilo-years ago).

\section{Rescue excavation project related to the resettlement of the Fourth Cataract population}

As part of a salvage project related to the construction of a dam on the Fourth Cataract, a survey was carried out in 2003 on several Palaeolithic sites, as well as extensive field research on early-Holocene sites in Multaga (Geus and Lecointe 2003; Garcea 2003). The occurrence of Palaeolithic assemblages was revealed in alluvial terraces (silts, gravels) corresponding to three stages of accumulation (with no reference to the previous findings of the CPE). The oldest stage was determined by the layering of sandy clay of a red-brown colour. Although there were artefacts made of local chert manufactured using Levallois or discoid methods, no bifacial products were recorded. Due to the low number of specimens, this material was described as related 
to the Nubian technocomplex. The next stage of sedimentation in the studied area was initiated by the erosion of the uppermost parts of older units. The only indication of the absolute chronology of the gravels deposited during this episode is as the result of the radiocarbon dating of shells, which went beyond the method's range, e.g., > $40 \mathrm{ka}$ (Williams et al., 20IO). These deposits contained collections of lithics of a similar raw material and with Middle Palaeolithic technological characteristics, although tools with shaped tangs appeared among retouched forms. According to the author of the study (Garcea 2003), these last elements testify to the impact of the Aterian technocomplex on the lithic traditions of the Middle Nile Valley. The youngest deposits in this part of the record had surface layers known as Holocene paleosoil remnants. In addition to single Palaeolithic items, numerous Early Holocene artefacts were recorded there.

Additionally, extensive settlements, identified as early Holocene in age, bore traces of advanced erosion - no stratigraphy or cut features were found, despite the seemingly good state of preservation of the artefacts themselves. Attempts at radiocarbon dating of chaff-tempered pottery have produced positive results and allow the time of the functioning of early Neolithic/Mesolithic settlements to be dated to the second half of the 7 th millennium BC $(c .7500 \mathrm{BP}$ after Gatto $2006=c .6400 \mathrm{cal} \mathrm{BC})$.

Among nearly a hundred Holocene sites, the vast majority comprised small clusters of archaeological material and small pebbles. In many cases, exploration revealed that these were the remains of Neolithic burials (Geus and Lecointe, 2003; Peressinotto et al., 2004). Their characteristic feature in relation to other Neolithic cemeteries in the Sudanese section of the Nile valley was the scattering of single burials over a large area. The authors of the study interpreted this phenomenon as reflecting the nomadic character of the culture in the Southern Dongola Reach at that time. Numerous finds of ceramic vessels - including caliciform beakers and two $14 \mathrm{C}$ dates - allowed one to determine the approximate age of these burials to a period between 4550 and 4250 BC (after Salvatori and Usai 2008: Fig. 13.7).

\section{PREHISTORY OF THE RIGHT BANK OF THE NILE IN THE SOUTHERN DONGOLA REACH}

\section{Preliminary studies of Jebel Kobkabba site}

The site of Jebel Kobkabba (Kobusiewicz and Kabaciński 1996) was explored in 1994. It was a lithic workshop located on an outcrop of ferruginous sandstone. The large accumulation of artefacts in a relatively small space $(100 \times 50 \mathrm{~m})$ and its location on the flat top of small hill resulted in the selection. The site was located about $1600 \mathrm{~m}$ east of the river, about $25 \mathrm{~m}$ above the present-day floodplain. Sediments containing Palaeolithic artefacts were not associated with the river accumulation. In both exposed 
soil profiles, only two horizons were visible (the upper one about $20 \mathrm{~cm}$ thick, yellowgrey in colour; and the bottom one reaching the bedrock at a depth of about $40 \mathrm{~cm}$, reddish in colour), a record of the different conditions for the precipitation of iron oxides. Most of the artefacts lay on the modern surface, although individual artefacts (bearing traces of much less intense erosion) were also recorded in both subsurface horizons. According to the authors, the lithics had remained in an undisturbed position. Among more than 700 artefacts, there were handaxes, tools of a chopper type, numerous discoidal cores and the most numerous artefacts, namely flakes from centripetal reduction. Taxonomically, the assemblage from Jebel Kobkabba was assigned to the Mousterian technocomplex known from CPE studies between the Second and First Cataracts, while the presence of handaxes was an indication of the B variant (after Marks 1968). The nature of the site was defined as a multiple-use workshop located directly on the outcrops of the raw material, namely ferruginous sandstone.

\section{The Southern Dongola Reach Survey}

Since 1997, the right-bank section of the valley, from Old Dongola to the suburbs of Karima, became a research area of the Polish Combined Archaeological Expedition to the Middle Nile Valley, led by Bogdan Żurawski (Żurawski 2003). The project known as the Southern Dongola Reach Survey, was aimed at understanding archaeological settlement patterns. Among almost one thousand recorded archaeological sites, there were nine loci with handaxes, I30 locations containing lithic artefacts of the Levallois tradition and 155 sites with correlates of microlithic traditions (Osypiński 2003). Due to the nature of the available data, namely random surface collections, a lack of defined geomorphological contexts and absolute dating, determination of their taxonomic affiliation proved to be extremely difficult. Based on the analysis of morphology and technology of lithics manufacturing, only a general division of assemblages was conducted, indicating four categories (Morpho-Technological Categories - MTC) that corresponded generally to the "modes" as proposed by G. Clark (1969). There was a lack of assemblages corresponding to the oldest, namely pre-Acheulian manufacturing traditions, and pre-Holocene blade traditions (non-microlithic). On the other hand, doubts arose due to microlithic sets that were not accompanied by the finding of ceramic fragments (MTC III). Although they could be interpreted as the remnants of settlement of late-Palaeolithic groups (analogically to Lower Nubia), they could also be highly eroded early-Holocene sites.

While the surface research phase of the project was completed in 2002, its results still need to be verified and refined. They do, however, indicate the great potential of the prehistoric sites in the Southern Dongola Reach, both those appearing on the surface of river sediments, as well as in the contexts preceding the modern hydromorphological regime of the Nile. 


\section{The Contribution of the Affad Project}

The continuation of the SDRS research project is referred to as the PalaeoAffad project - although it is primarily focused on the exploration of Affad 23, in subsequent stages this includes numerous aspects of prehistoric settlement in the micro-region of the Affad Basin. Its assumption is to use the potential of the Southern Dongola Reach sites, as well as modern research methods, to provide important data for the modelling of the prehistory of the middle section of the Nile Valley.

First of all, surface reconnaissance of the archaeological landscape was supplemented by the penetration of areas adjacent to the land-belt surveyed by the SDRS (Osypińska and Osypiński 20I6a). Several dozen new locations have been recorded, revealing, among other things, the legacy of the penetration of the valley surroundings by groups using handaxes, as well as a number of small sepulchral sites dated to the period of late prehistory.

From the very beginning, the project was accompanied by a team of specialists whose task was to reconstruct the paleogeography of the Affad Basin corresponding to the subsequent periods of human settlement (Fig. 3). In addition to the standard methods of stratifigraphic analysis (including granulometry and magnetic susceptibility

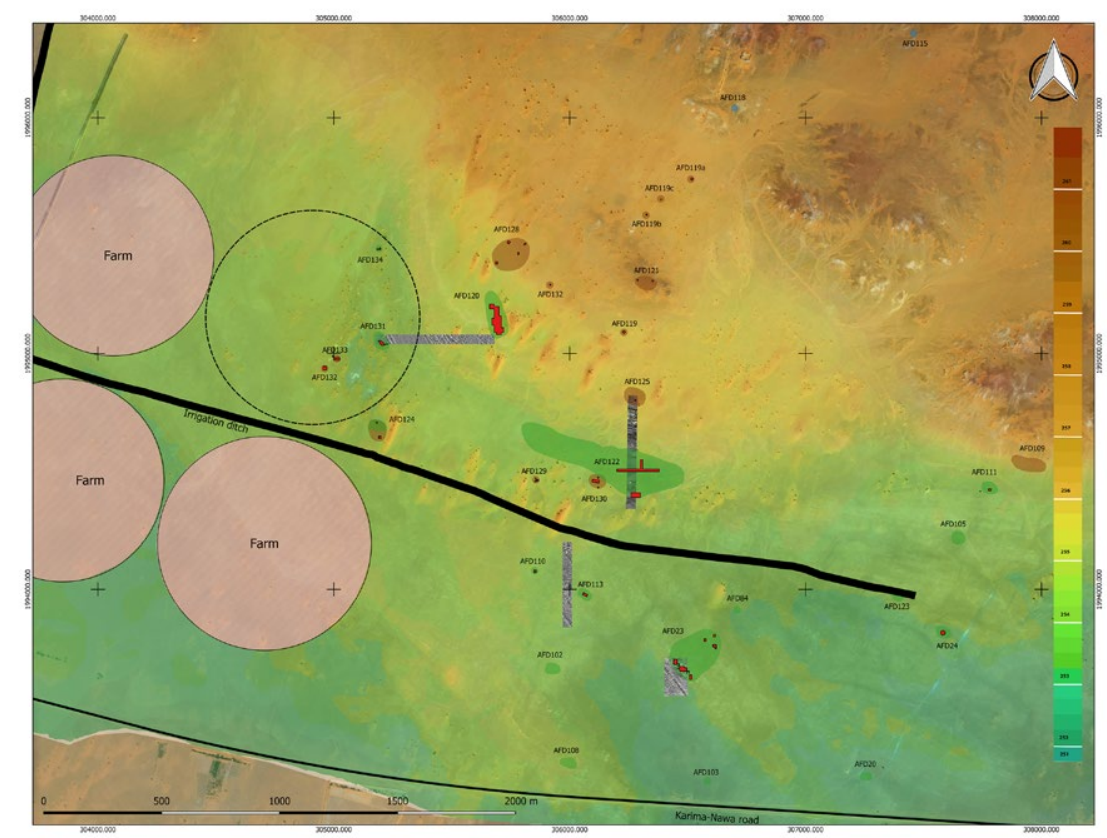

Fig. 3. Compilation of the hipsographic plan, results of magnetometric imaging and satellite image with the location of prehistoric sites at the Affad Basin.

Measurements and ESRI image: P. Wiktorowicz and R. Ryndziewicz. 
measurements) and a suite of dating methods, a magnetic prospection with a fluxgate gradiometer was used to show shifts in the network of river paleochannels - in the context of settlement in the late Pleistocene. Analyses of the contemporary land relief using high resolution measurements of large spaces compiled with satellite images has enabled studies on the human strategies for changing the exploitation of environmental resources.

\section{First signs of human occupation (until MIS5)}

The oldest part of the Affad Basin landscape is the edge of the upland section closing off the research area from the north. Both currently and during the late Pleistocene, sandstone inselbergs of Mesozoic rocks dominated this area and were the source used for obtaining raw material for making stone tools, namely ferruginous and quartzite sandstones.

Extensive lithic workshops on the tops of inselbergs, including both handaxes and the waste of the flake production methods, are known from both the SDRS research project and the current stage of research. The chronology of these assemblages undoubtedly covers an extremely long time, as this raw material was still being used in very recent times for the production of grinding stones. However, these sites were all surface loci, along with the clusters of handaxes at sites Afd115 and Afd118, indicating penetration of the lower parts of the valley by the oldest groups of hominins. The composition of these assemblages, limited to various-sized handaxes, exclusively suggests a strictly defined site function. Undoubtedly, these were remnants of shortterm visits related to food supplies, although it is impossible to indicate the time of duration of these episodes. Analogous tools were used in this part of Africa by presapient hominins, whose production is attributed to the global Acheulean tradition, as well as by much later traditions - most likely that of early Homo sapiens (Nubian Mousterian variety B, or Sangoan). Due to the presence of only handaxes in these small collections, it is much less plausible to assume their later reutilisation (by analogy to the find at the Afd119 site, where a handaxe was used to fasten a much-later shelter pole). Thus, if one assumes a chronological identity for the creation, utilisation and abandonment of tools from Afd115 and Afd118, it should be noted that the soil in which they were originally deposited has been completely eroded by now. The artefacts were collected from the surface of the sandstone bedrock carved by heavy rains flowing down towards the valley, at least since the Middle Holocene (Fig. 4). In the adjacent area, single finds of lithic artefacts of later date (both late Pleistocene and Holocene) were also found.

Although sites of the Jebel Kobkabba type are not known from the Affad Basin, the presence of single sandstone bifacial points are interpreted as a reflection of the reuse of tools from local Early-Middle Stone Age (MSA) sites. One of these tools was found on the surface at location Afd108 (Osypińska and Osypiński 20I6a: Fig. 9a). The products of this type were typical for the Lupemban industry and the early Nubian Complex 


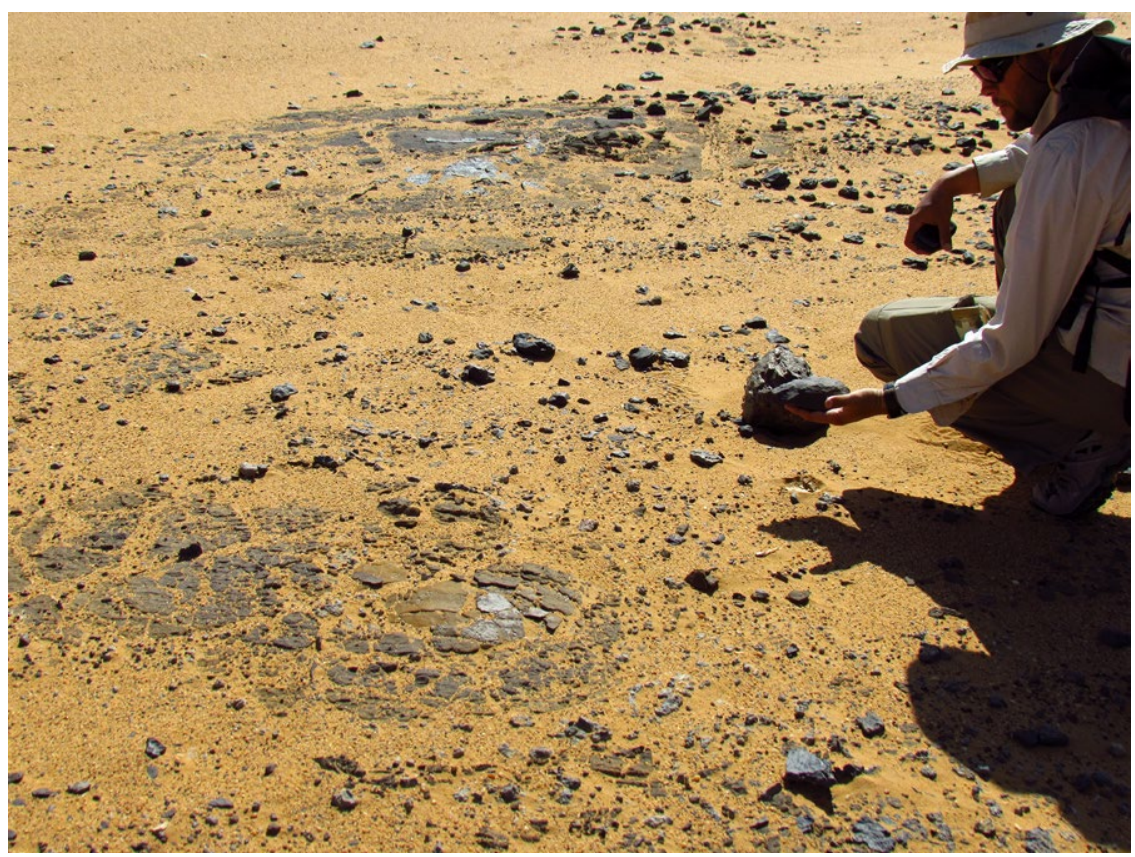

Fig. 4. Handaxes from Afd115 at the time of discovery. Photo: M. Osypińska.

(Van Peer 20I6) and should generally be dated to the beginnings of MIS5. Nevertheless, the original sites dated to this period have not survived up to today. OSL (Optically Stimulated Luminescence) dating of reddish sands directly below coarse gravels from the northern part of the Affad Basin, indicate an MIS5 chronology. The composition and location of $c$. I $\mathrm{m}$ thick gravels indicate the high energy of the river flows during formation and reflect the bottom of the valley directly at the beginning of next stage of downcutting. Unfortunately, the OSL dates of gravels themselves seem unreliable (see Table I marked in red). Attempts to analyse shells of molluscs taken from gravels by $14 \mathrm{C}$ has not helped either - The Early Holocene results most probably reflect just the recrystallization stage of calcite (see also: Dal Sasso et al., 20I8). It was only after the occurrence of the incision of the river bed that the sediments of the next stage of aggradation accumulated.

\section{Late MSA occupation scatters}

The most important sites of the late-MSA from Affad were recorded in the top parts of the alluvial units dated to 56-46 ka. Although the first series of OSL dates (Kalicki and Olszak 20I6) suggested a much younger chronology (c. I6 ka), currently available data make it necessary to revise previous estimates. The new series of OSL dates are supported by TL, ESR and, indirectly, radiocarbon dates. 
Most of data on the chronology of late-MSA occupation came from site Afd23. Both sediments preceding the settling phase $(60.11 \pm 8.70 ; 57.83 \pm 9.69)$, that directly related to it $(56.8 \pm 4.8 ; 53.95 \pm 8.36)$ and that even later than the settlement episode $(42.53 \pm 6.36)$ were OSL-dated. ${ }^{2}$ In addition, the chronology of this settlement phase was determined by TL (Thermoluminescence) dating of the baked alluvium (46.4 \pm 4.0 ). A similar chronology was indicated by OSL dating of a sediment in which Aurochs remains from site Afd124 occurred (4I.7 \pm 4.8 ), although a slight rejuvenation of this result should be assumed due to the shallow depth of the collected sample (about IO- $20 \mathrm{~cm}$ ). Additionally, TL dating of a baked substrate at site Afd134 (56.I \pm 6.8$)$ supports the implication of the $14 \mathrm{C}$ result of a shell from this location $(>48 \mathrm{ka}) .^{3}$ The dating of 4 teeth samples by the ESR method ${ }^{4}$ from sites Afd 23 and Afd 24 needs more studies and seems to be a methodological challenge, indicating much older age $(78 \pm 9 \mathrm{ka}$ up to $\mathrm{I} 6 \mathrm{O} \pm \mathrm{II} \mathrm{ka})$. It should be added that the contemporary age of locations Afd23, Afd105 and Afd111 was suggested by the results of previous analyses conducted by a laboratory in Kielce, Poland.

One of the most important assets of the MSA sites from the Affad Basin is their contemporaneity and simultaneous functional differentiation. In addition to the sites where remnants of light wooden constructions and campfires have survived (Afd23 - Osypiński et al., 20I6; Afd24 - Fig. 5), there were loci without such elements, though undoubtedly also serving as encampments (an interpretation that the composition of the stone and bone inventories supports) - e.g., sites Afd111, Afd131. In turn, analogous sites located in slightly higher terrain, namely Afd120 and Afd122, have undergone far-reaching erosion. A completely different category of sites was dominated by organic remains that mark temporary sites linked with episodes of food procurement. In addition to the classic examples of killing/butchering sites (Afd124, Afd110, Afd105), loci at which there were exclusively fish remains (Afd113, Afd112) or molluscs shells (Afd134) were also found. Further differences between the late-Pleistocene camp-sites were revealed by the analysis of the composition of the stone and bone finds assemblages. Assemblages dominated by chert artefacts (e.g., Afd23, Afd24) occurred in the zone slightly further from the edge of the valley, in contrast to those in which ferruginous sandstone was dominant (e.g., Afd111, Afd131). Access to pebbles exposed by the river seemed to be the main reason for settling site Afd23. Due to numerous refits, it was found that not only producing tools of this raw material took place, but also the learning of rock processing (Osypiński and Osypińska 20r6). The composition of fauna

2 The new series of OSL and TL samples were analysed in UMCS laboratory in Lublin (Dr Karol Standzikowski).

3 AMS 14C datings were performed in the radiocarbon laboratory in Poznan (Prof. Tomasz Goslar).

4 ESR method datings were performed in the Williams College laboratory (Dr Anne Skinner) but still require more studies. 


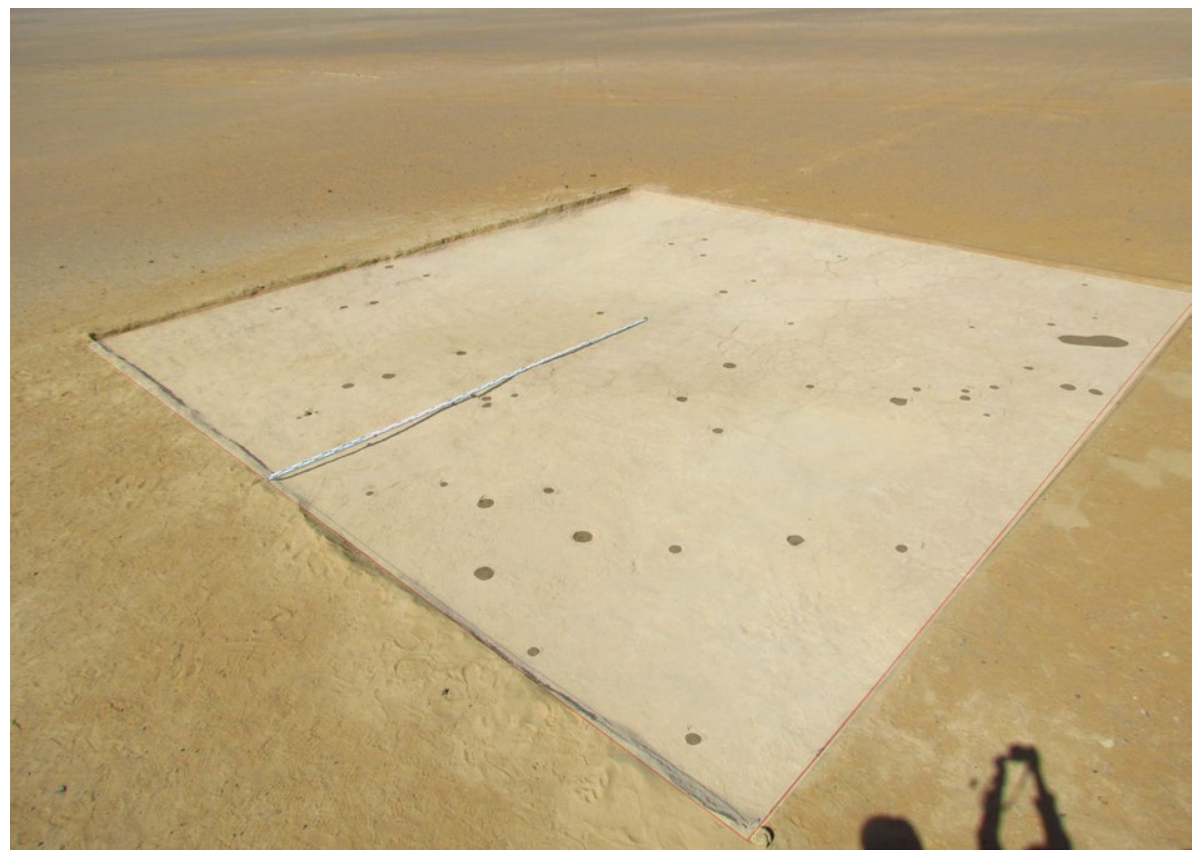

Fig. 5. Postholes (relics of light wooden constructions) unveiled at the Afd24 site. Compilation of photos and drawings: P. Osypiński.

from this site indicated a wide range of hunting preferences including both megafauna: hippopotamus (Hippopotamus amphibius); large ruminants, such as aurochs (Bos primigenius) or buffalo (Syncerus caffer), Kob antelopes (Kob sp.), Oribi (Ourebia ourebi), bohor reedbuck (Redunca redunca); as well as small mammals such as grivets (Chlorocebus aetiops), Salt's dik-dik (Madoqua saltiana) and the cane rat (Thryonomys swinderianus). An analogous composition was also noted at the Afd111 site, although the basic raw material for making stone tools there was sandstone. The list of species that was noted at these sites seems to create a very cohesive whole, in ecological terms. All species recorded there inhabit backwaters, marshes, or at least, the close vicinity of bodies of water. Stratigraphic, geomorphological and archeozoological analyses suggest that the Affad Basin was most likely a seasonal hunting area visited during the dry season. It was a time of grouping antelopes, especially Kob, into large herds around the relatively small watering holes remaining after the rainy season. The clear dominance of the remains of this species suggests a certain specialisation in hunting. Both females, males, as well as offspring of close-to-adult size, were hunted. However, we do not have data on the trapping of small calves. On elevated terrain, the small 
camps were set up by hunters, while animal carcass (small game) processing zones were organized in the vicinity. Such a model was indicated by two locations identified at site Afd 23 (areas NE and S, while area SW was a camp: Osypińska and Osypiński 2016b: Figs. 3, 4, 5).

At loci Afd131 and Afd24, the lists of identified animal species were different. The recorded remains came mainly from mammals and, to a much lesser extent, from fish. An example of well-preserved relationships in terms of spatial and anatomical positioning of remains was site Afd131. In its "central" part, an accumulation of both lithics and numerous clusters of anatomically contiguous skeletal elements were found. These were the remains of a large bovid (most likely aurochs), mainly vertebrae, ribs and fragments of long bones and teeth. The remains of medium-sized antelopes (hartbeest, kob) and gazelles were clearly less frequent. The least numerous remains were those of fish, mainly Claridae being identified. Within a radius of several dozen metres of the zone with the largest concentration of artefacts, smaller clusters or individual bones and teeth were also recorded. They came from animals representing various taxa: rodents equines, giraffes, hippopotamus, ungulates, and canines. Based on the archaeozoological data, it was possible to identify, in the NW part of the Affad Basin, MSA sites with a different hunting model than that already known from the southern and eastern areas. This was indicated by a preference for hunting for large ruminants - mainly aurochs, as well as equines (zebras) and giraffes. At the same time, "less valuable" animals, meaning those more aggressive or very small, were not in the field of hunting interests.

Research in Affad supports the thesis of a high degree of behavioural flexibility among humans during the late Pleistocene. The main factor in shaping their diet, but also selection of raw materials, was their availability - that is, a given group of animals or rocks. The "broad" model present at Affad sites 23 and 111, namely one with a large proportion of medium and small animals, but also with the presence of megafauna, reflects the exploration of a closed environment, such as forest or floodplain. The exploitation of this zone was possible mainly during the dry season (winter), which also suggests free access to chert pebbles. Undoubtedly, the location of site Afd134, where a cluster of baked shells of molluscs was discovered, also had to be exploited at low water levels. The second model corresponds to the exploitation of the environment during the rainy season, at a distance from the flood zone, then inaccessible or too dangerous. Groups of people could then move to areas located a little higher, to the area of the savannah inhabited by large ruminants, namely aurochs, giraffes, larger antelopes. A characteristic feature of the artefacts from these loci was the lack or low use of chert as a raw material for the production of tools. At sites with dominant shares of large ruminant remains, ferruginous sandstone, which was easy to obtain on a plateau approximately $4 \mathrm{~km}$ away, was definitely preferred as a raw material. Harvesting fish at site Afd113 also had to take place at the beginning of the rainy season - almost 
$92 \mid$ M. Osypinska, P. Osypinski, M. Chtodnicki, M. Kuc, P. Wiktorowicz and R. Ryndziewicz

exclusively fish of one species (Clarias sp.) was caught there, with a strictly limited size range, most likely during their spawning season. ${ }^{5}$

An undoubtedly important discovery was the remains of aurochs at several sites (Afd124, Afd131, Afd120). Currently, these are the southernmost loci of this extinct species in Africa and direct evidence of the presence of aurochs in the hunting consciousness of members of late-MSA groups in the middle part of the Nile valley.

\section{Early holocene (re-)settlement}

The later history of the Affad Basin formation meant a shift to the south of the river bed and the beginning of the ongoing erosion of the upper layers of sites. Although extensive early Holocene sites usually abound in ceramic material, this only appears on the modern surface. Clusters of surface artefacts suggested the original location of larger cut features, namely storage pits, the fills of which had concerntrated artefactual material (Fig. 6). Only at site Afd69 were there still preserved the lower parts of such features (Fig. 7). The remains of fish and wild fauna (the jaws of hyenas), as well as a rich set of stone artefacts (mainly made of quartz) and potsherds, were found in their fills.

Considering the positive results of the radiocarbon dating of potsherds tempered with an organic admixture from Multaga, several fragments of such material from Affad were also selected for analyses. The obtained results (Afd125 $=7460 \pm 40 \mathrm{BP}$ : 6416-624I cal BC [95.4\%]; Afd128 = 7880 \pm 40 BP: $6842-6636 \mathrm{cal} \mathrm{BC} \mathrm{[85.3 \% ];}$ Afd121/1 = 7800 \pm 50 BP: 6767-6496 cal BC [95.4\%]; Afd121/2 = 7910 \pm 50 BP: 6863-6649 cal BC $[65.7 \%])$ correlate with those from the opposite bank of the river.

\section{Neolithic nomad remnants}

Neolithic burials recorded quite numerously in the Affad Basin area also corresponded to the finds from the opposite bank of the Nile and were characterized by large dispersion. Their state of preservation (exposure of the skeletons originally deposited in pits by erosion of the substrates - Fig. 8) suggests that the original number of burials could have been higher, although it certainly did not match the cemeteries known from the areas adjacent to the north (R12, Kadruka) and located in the upper reaches of the Nile (Kadada, Kadero). Radiocarbon dating of the burial equipment allowed one to date the sepulchral activity of shepherd groups to between $6030 \pm 40 \mathrm{BP}: 5034-4829 \mathrm{cal} \mathrm{BC}$ [94.3\%] (Afd119) and 5730 4 0 BP: 4226-3930 cal BC [95.4\%] (Afd130). A unique feature of one of the cemeteries, namely Afd130, was the coexistence of human and animal burials (cattle and small ruminants). Additionally, at site Afd69 (C/VII/51) the occurrence of a series of small clusters of bovine bones in the vicinity of human burials was recorded. They provided unique data on the morphology of domesticated

\footnotetext{
5 Ichtyological analysis performed by Dr Veerle Linseele.
} 


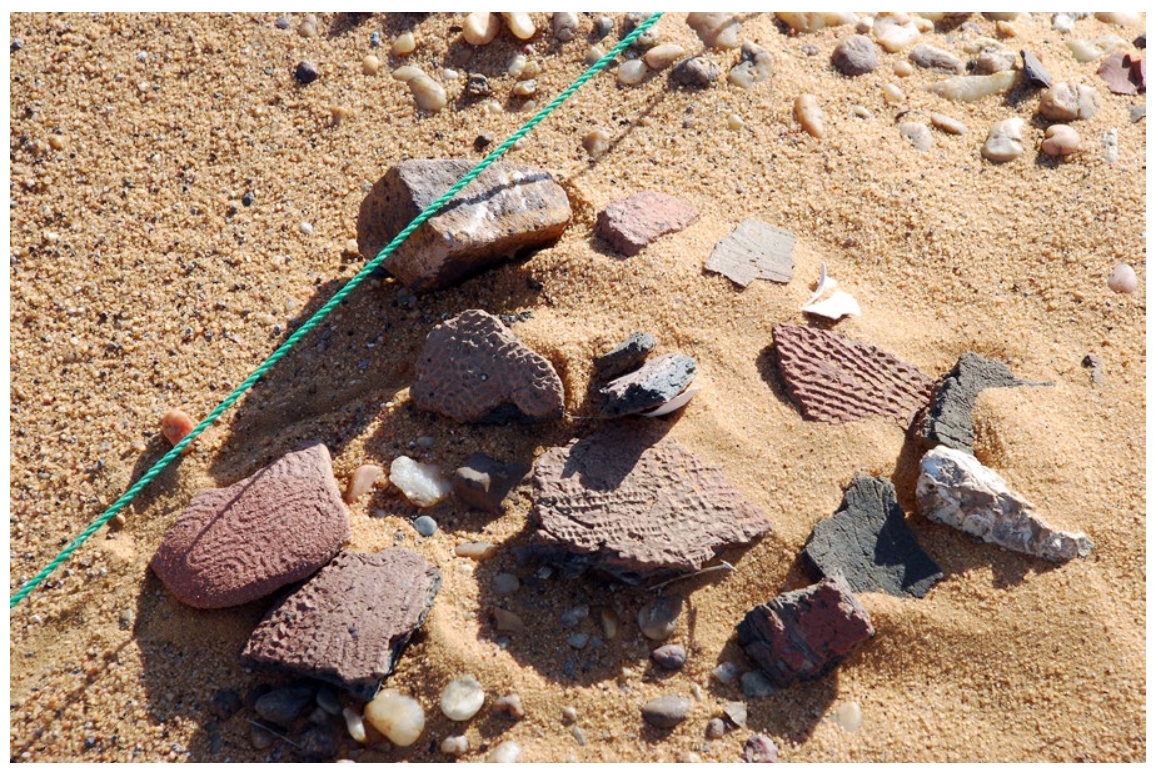

Fig. 6. Early Holocene potsherds cluster (eroded fill of a cut feature) - Afd125. Photo: P. Osypiński.

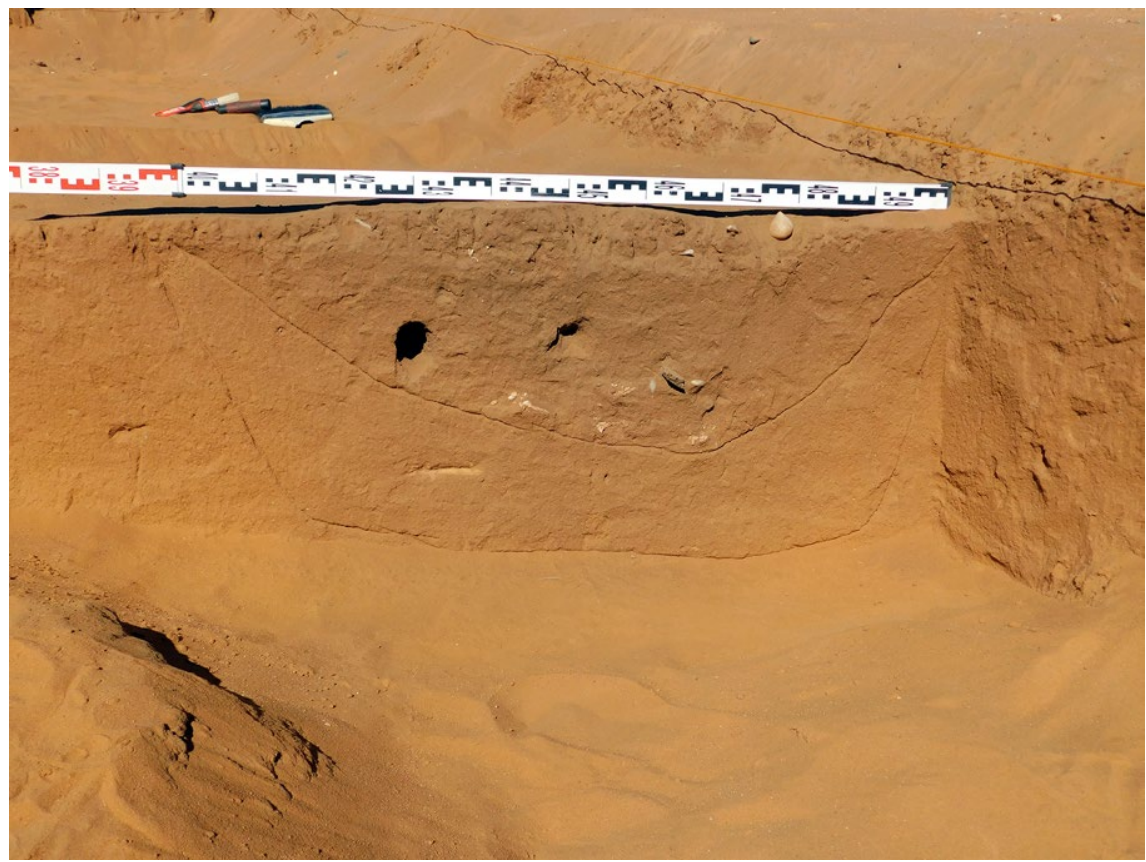

Fig. 7. Section of the early-Holocene storage pit at Afd69 C/VII/91. Photo: P. Osypiński. 


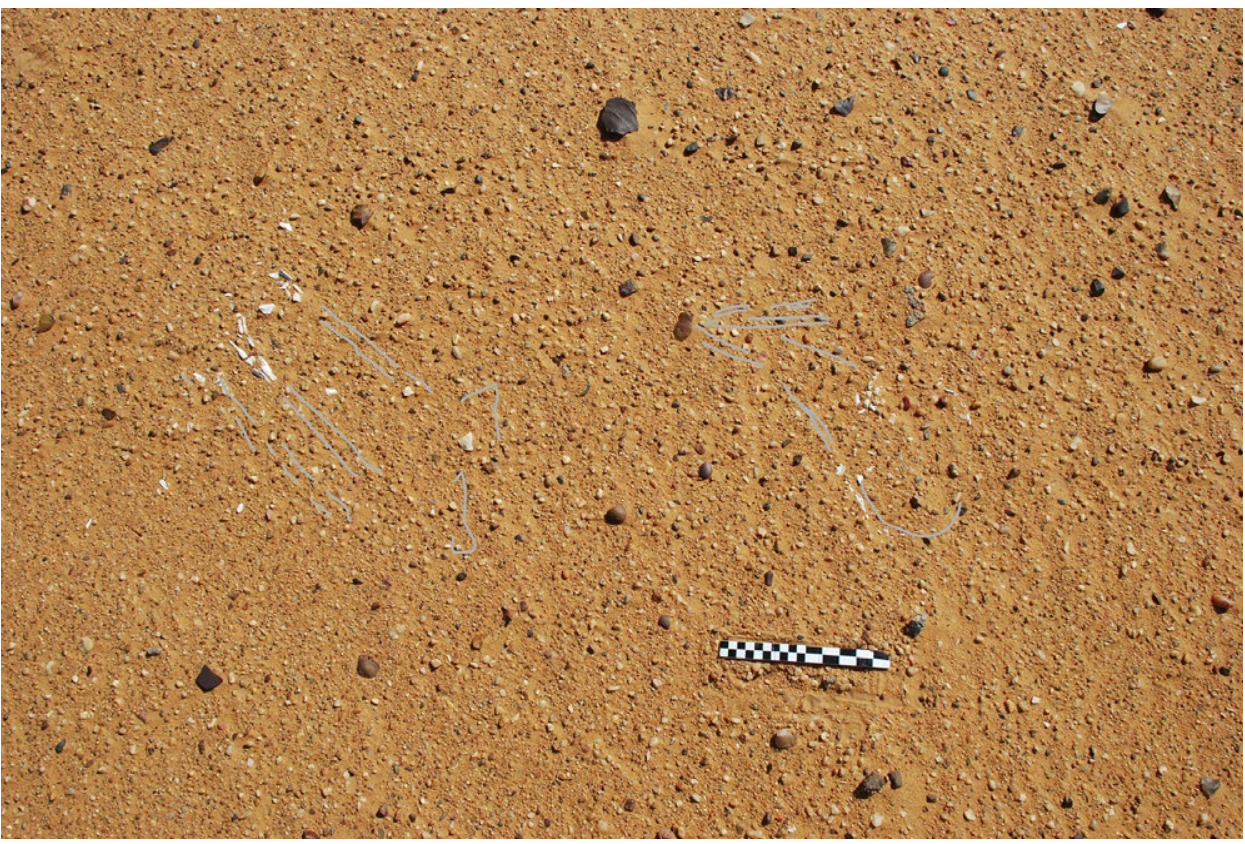

Fig. 8. Eroded Neolithic burial recorded on the present day surface - Afd69 B/VIII/52 gr 1 (digital reconstruction of the original position of skeleton in gray). Photo: M. Chłodnicki.

animals from this period. Preliminary results of lipid analyses from Neolithic vessels indicated the dairy use of ruminants ${ }^{6}$ (most likely cattle). This indication is also probably supported by the finding of fragments of strainer vessels from Afd69, linked to the production of cheese. Naturally, although this record does not indicate a breeding model oriented solely on the use of non-meat products, it is important proxy data for studies on the evolution of people's adaptation to the changing sub-Saharan Africa environment. Analysis of Strontium isotopes in the dental enamel of both humans and Neolithic animals ${ }^{7}$ revealed a wide range of indications, pointing the local values for shepherds' groups that buried their dead in the studied area. On the other hand, the comparison of these data with the indications from Pleistocene samples shows the transformation of the environment (desertification) of the Affad Basin over fifty millennia.

6 The analysis was performed in the laboratory of the Organic Geochemistry Unit, School of Chemistry, University of Bristol (Dr Julie Dunne).

7 The analysis was performed in the isotopic laboratory of the A. Mickiewicz University in Poznan (Prof. Zdzisław Bełka). 


\section{LOSS OF THE PREHISTORIC HERITAGE OF THE MIDDLE PART OF THE NILE VALLEY - THE EXAMPLE OF THE AFFAD BASIN}

Just two decades of research in northern Sudan has allowed one to observe the gigantic scale of destruction of prehistoric sites. These unusually discreet elements of the archaeological landscape recorded outside the area of direct interest of the local farming population, have not been threatened for a long time. The situation has changed dramatically since the construction of a dam at the Fourth Cataract and general electrification of the Northern Province (Shimaliyah). The rescue operation in Multaga in 2003 preceded the construction of new settlements and fields for the population of the area to be flooded - these sites ceased to exist several months after the completion of archaeological works. In 2009, the construction of the Debba bridge and the road on the right bank of the river between Karima and Nawa, that passes just a few hundred metres south of site Afd23, were completed. The construction process has led to the destruction of at least several sites marked during the SDRS in the Affad district. Finally, in 20I6, on the right bank, agricultural projects sponsored by investors from the Persian Gulf led to the destruction of most of the archaeological sites located on the Nile terraces. Using heavy excavators, water supply channels for irrigation devices of several hundred metres in diameter have been created. Directly before the start of cultivation, not only was dune sand removed, but also the top layer of the ground, containing remnants of prehistoric settlement. Ad hoc attempts to mark the most important sites of the PalaeoAffad project proved to be pointless. As these prehistoric sites did not contain such permanent and clear elements as architecture, it was extremely difficult to convince the local community of the need to protect them.

It is hard to not to perceive the research conducted in Affad - or even wider - in Southern Dongola Reach, as invaluable for documenting an archaeological landscape which no longer exists. It seems that we are losing more and more opportunities to get answers to many important questions, the importance of which extends beyond the narrow space of the Southern Dongola Reach. These include both the role of the middle section of the Nile valley, considered as a key migration corridor during the period when early members of our species left Africa, and the subject of the extremely late persistence of archaic Levallois lithic traditions until the end of Pleistocene. We are losing also the opportunity to obtain valuable data on the early stages of cattle domestication in Africa, as well as the sources of the mosaic nature of the so-called cattle centred behaviour cultures, whose past we may observe even today in the area of subSaharan Africa. 
96 M. Osypinska, P. Osypinski, M. Chtodnicki, M. Kuc, P. Wiktorowicz and R. Ryndziewicz

\section{REFERENCES}

Clark, G. 1969. World Prehistory: A New Synthesis. Cambridge, Cambridge University Press.

Dal Sasso, G., Zerboni, A., Maritan, L., Angelini, I., Compostella, C., Usai, D. and Artioli, G. 20I8. Radiocarbon dating reveals the timing of formation and development of pedogenic calcium carbonate concretions in Central Sudan during the Holocene. Geochimica et Cosmochimica Acta 238: 16-35.

de Heinzelin, J. 1968. Survey in the Debba-Korti Area. Kush i5: 59-69.

Garcea, E. A. 2003. Palaeolithic sites at El-Multaga. Nyame Akuma 59: 62-65.

Gatto, M. C. 2006. The Most Ancient Pottery from the Dongola Reach (Northern Sudan): New Data from the SFDAS Survey Related to the Construction of the Merowe Dam. Archéologie du Nil Moyen I0: $73-86$.

Geus, F. and Lecointe, Y. 2003. Survey and Excavation at el-Multaga, a Resettlement Area Related to the Construction of the Merowe Dam: Preliminary Results. Sudan \& Nubia 7: 33-40.

Hays, T. R. I97ıa. The Karmakol Industry: Part of the "Khartoum Horizon-Style”. In J. L. Shiner (ed.), The Prehistory and Geology of Northern Sudan, vol. I, 84-153. Washington. Report of the National Science Foundation GS IIg2.

Hays, T. R. 197Ib. The Tegris Industry. In J. L. Shiner (ed.), The Prehistory and Geology of Northern Sudan, vol. I, I54-I86. Washington, Report of the National Science Foundation GS II92.

Kalicki, T. and Olszak, I. 20I6. Supplementary materials for: Osypiński, P., Morley, M., Osypińska, M. and Kotarba-Morley, A. 2016. Affad 23: settlement structures and palaeoenvironments in the Terminal Pleistocene of the Middle Nile Valley, Sudan. Antiquity 90(352), available at: https://static. cambridge.org/content/id/urn:cambridge.org:id:article:S0003598X16001101/resource/name/ S0003598X16001101sup001.pdf

Kobusiewicz, M. and Kabaciński, J. 1996. Jebel Kobkabba: a Middle Palaeolithic site in Sudanese Nubia. In L. Krzyżaniak, K. Kroeper and M. Kobusiewicz (eds), Interregional Contacts in the Latter Prehistory of Northeastern Africa, 355-375. Poznań, Poznan Archaeological Museum.

Marks, A. E. 1968. The Mousterian Industries of Nubia. In F. Wendorf (ed.), Prehistory of Nubia, 194-314. Dallas, Fort Burgwin Research Center and Southern Methodist University Press.

Marks, A. and Ferring, C. R. 197I. The Karat Group: an early Ceramic Occupation of the Dongola Reach, Sudan. In J. L. Shiner (ed.), The Prehistory and Geology of Northern Sudan, vol. I, I87-275. Washington. Report of the National Science Foundation GS II92.

Marks, A., Hays, T. and de Heinzelin, J. 1968. Preliminary Report of the Southern Methodist University Expedition in the Dongola Reach. Kush I5: 165-192.

Osypińska, M. and Osypiński, P. 20ı6a. Lavallois Tradition Epigones in the Middle Nile Valley: Survey in the Affad Basin. Polish Archaeology in the Mediterranean 24(I): 60I-626.

Osypinska, M. and Osypinski, P. 2or6b. Animal Exploitation and Behaviour of the Latest Middle Stone Age Societies in the Middle Nile Valley: Archaeozoological and Taphonomic Analysis of Late Pleistocene Fauna from the Affad Basin, Sudan. African Archaeological Review 33(2): IO7-I27.

Osypiński, P. 2003. Southern Dongola Reach in Prehistory. In B. T. Żurawski (ed.), Survey and Excavations between Old Dongola and Ez-Zuma, 463-467. Warszawa.

Osypiński, P., Morley, M., Osypińska, M. and Kotarba-Morley, A. 20I6. Affad 23: settlement structures and palaeoenvironments in the Terminal Pleistocene of the Middle Nile Valley, Sudan. Antiquity 90(352): 894-913. 
Osypiński, P. and Osypińska, M. 2016. Optimal Adjustment or cultural backwardness? New data on the latest Leallois industries in the Nile Valley. Quaternary International 408 (Part B): 90-I05.

Peressinotto, D., Schmitt, A., Lecointe, Y., Pouriel, R. and Geus, F. 2004. Neolithic nomads at El Multaga, Upper Nubia, Sudan. Antiquity 78(299): 54-60.

Salvatori, S. and Usai, D. (eds). 2008. A Neolithic Cemetery in the Northern Dongola Reach: Excavation at Site R12. Oxford, Sudan Archaeological Research Society Publication Number I6. British Archaeological Reports International Series I8I4.

Shiner, J. L. 197I. El Melik Group. In J. L. Shiner (ed.), The Prehistory and Geology of Northern Sudan, vol. I, 276-290. Washington, Report of the National Science Foundation GS II92.

Van Peer, P. 20i6. Technological Systems, Population Dynamics, and Historical Process in the MSA of Northern Africa. In S. C. Jones and B. A. Stewart (eds), Africa from MIS 6-2: Population Dynamics and Paleoenvironments, I47-I59. Dordrecht, Springer Science+Business Media.

Wendorf, F. 1968. Prehistory of Nubia. Dallas, Fort Burgwin Research Center and Southern Methodist University Press.

Wendorf, F. and Schild, R. 1992. The Middle Palaeolithic of North Africa: A status Report. In F. Klees and R. Kuper (eds), New Light on the Northeastern African Past. Current Prehistoric Research, 39-80. Cologne, Heinrich Barth Institut.

Williams, M.A. J, Williams, F. M., Duller, G. A.T., Munro, R. N., El Tom, O. A. M., Barrows, T.T., Macklin, M., Woodward, J., Talbot, M. R., Haberlah, D. and Fluin, J. 20Io. Late Quaternary floods and droughts in the Nile valley, Sudan: new evidence from optically stimulated luminescence and AMS radiocarbon dating. Quaternary Science Reviews 29: III6-II37.

Zurawski, B. T. 2003. Survey and Excavations between Old Dongola and Ez-Zuma. Warszawa, Neriton. 
